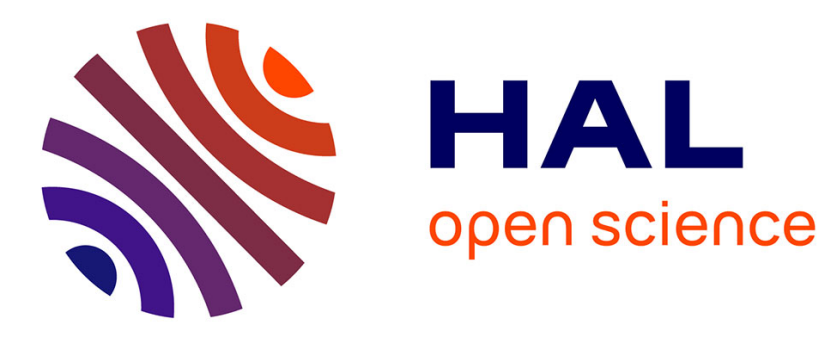

\title{
Cytotoxic indole alkaloids from Pseudovibrio denitrificans BBCC725
}

\author{
Alice M.S. Rodrigues, Clémence Rohée, Thibaut Fabre, Nicole Batailler, \\ François Sautel, Isabelle Carletti, Stéphanie Nogues, Marcelino T. Suzuki, \\ Didier Stien
}

\section{To cite this version:}

Alice M.S. Rodrigues, Clémence Rohée, Thibaut Fabre, Nicole Batailler, François Sautel, et al.. Cytotoxic indole alkaloids from Pseudovibrio denitrificans BBCC725. Tetrahedron Letters, 2017, 58 (32), pp.3172-3173. 10.1016/j.tetlet.2017.07.005 . hal-01590793

\section{HAL Id: hal-01590793 https: / hal.sorbonne-universite.fr/hal-01590793}

Submitted on 20 Sep 2017

HAL is a multi-disciplinary open access archive for the deposit and dissemination of scientific research documents, whether they are published or not. The documents may come from teaching and research institutions in France or abroad, or from public or private research centers.
L'archive ouverte pluridisciplinaire HAL, est destinée au dépôt et à la diffusion de documents scientifiques de niveau recherche, publiés ou non, émanant des établissements d'enseignement et de recherche français ou étrangers, des laboratoires publics ou privés. 


\section{Accepted Manuscript}

Cytotoxic indoles alkaloid from Pseudovibrio denitrificans BBCC725

Alice M.S. Rodrigues, Clémence Rohée, Thibaut Fabre, Nicole Batailler, François Sautel, Isabelle Carletti, Stéphanie Nogues, Marcelino T. Suzuki, Didier Stien

PII: S0040-4039(17)30842-0

DOI: http://dx.doi.org/10.1016/j.tetlet.2017.07.005

Reference: TETL 49087

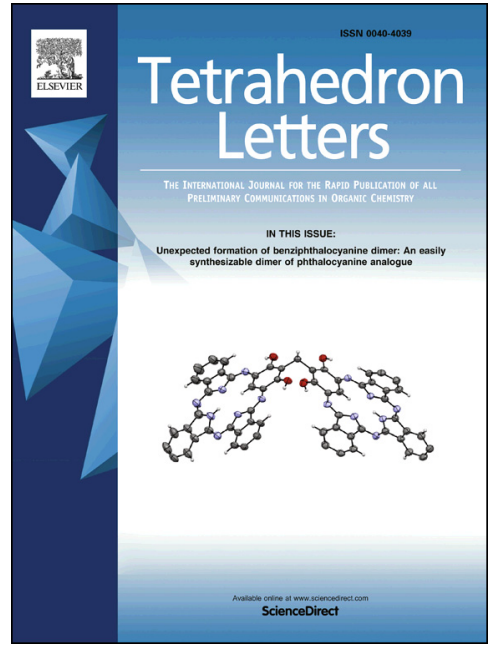

To appear in:

Tetrahedron Letters

Received Date:

12 May 2017

Revised Date:

22 June 2017

Accepted Date:

1 July 2017

Please cite this article as: Rodrigues, A.M.S., Rohée, C., Fabre, T., Batailler, N., Sautel, F., Carletti, I., Nogues, S., Suzuki, M.T., Stien, D., Cytotoxic indoles alkaloid from Pseudovibrio denitrificans BBCC725, Tetrahedron Letters (2017), doi: http://dx.doi.org/10.1016/j.tetlet.2017.07.005

This is a PDF file of an unedited manuscript that has been accepted for publication. As a service to our customers we are providing this early version of the manuscript. The manuscript will undergo copyediting, typesetting, and review of the resulting proof before it is published in its final form. Please note that during the production process errors may be discovered which could affect the content, and all legal disclaimers that apply to the journal pertain. 


\section{Cytotoxic indoles alkaloid from Pseudovibrio denitrificans BBCC725}

Alice M.S. Rodrigues ${ }^{a}$, Clémence Rohée ${ }^{a, b}$, Thibaut Fabre ${ }^{a}$, Nicole Batailler ${ }^{a}$, François Sautel ${ }^{b}$, Isabelle Carletti $^{b}$, Stéphanie Nogues ${ }^{b}$, Marcelino T. Suzuki ${ }^{a}$, Didier Stien ${ }^{a^{*}}$

a'Sorbonne Universités, UPMC Univ Paris 06, CNRS, Laboratoire de Biodiversité et Biotechnologies Microbiennes (LBBM), Observatoire Océanologique, Banyuls-sur-Mer, France

${ }^{\mathrm{b}}$ Institut de Recherche Pierre Fabre, Centre de Recherche \& Developpement, F-31035 Toulouse 1, France

* Corresponding author. Tel.: +33 4301924 76. E-mail address: didier.stien@cnrs.fr 


\section{Abstract:}

In this study, we investigated a culture supernatant of a Pseudovibrio denitrificans strain isolated from sea water. Five indole alkaloids were isolated from this culture. These include four known compounds, arundine (1), vibrindole A (2), 1,1,1-tris(indol-3-yl)methane (3), 7,7-bis(indol-3-yl)-pcresol (4) and the new tetra(indol-3-yl)ethanone (5). Compound 5 showed interesting cytotoxic effect against $\mathrm{L929}$ cells $\left(\mathrm{EC}_{50}=7 \mu \mathrm{M}\right)$ and $\mathrm{A} 549$ cells $\left(\mathrm{EC}_{50}=8 \mu \mathrm{M}\right)$.

\section{Keywords:}

Pseudovibrio denitrificans; Marine natural products; Indole alkaloids; Cytotoxic activity. 
The seas and oceans cover about 70\% of the Earth's surface, are complex, ancient and relatively poorly explored biotopes ${ }^{1,2}$ and thus, a source of unique natural products that may contain structural features not found in terrestrial sources. There are approximately $10^{6}$ prokaryotic cells per $\mathrm{ml}$ of surface seawater throughout the world's oceans ${ }^{3}$ and these microorganisms have developed unique metabolic and physiological capabilities that ensure their survival in a heterogeneous and fluid habitat (light, salinity, temperature nutrient gradients among others). These adaptations in many cases are dependent on specific bioactive compounds which in turn are a rich source for the discovery of new natural compounds.

For more than a decade our group has been building a collection of marine bacteria strains and a screening of different biological activities has been conducted using culture supernatants of these strains. Among these supernatants, those of a Pseudovibrio denitrificans BBCC725 culture showed interesting cytotoxic activities against a melanoma cell line, and was further investigated. Extraction of the secondary metabolites was conducted from centrifugation pellets (8500G during 10 minutes) of cells and sterile Amberlite XAD7 resin (160g of dry weight), that had been added 4 hours prior to a $10 \mathrm{~L}$ Marine Broth culture grown for 16 days at 25 degrees under static conditions. The pellet was macerated in methanol/acetone (1/1); the macerate was collected by filtration, evaporated, dissolved in water (1L) and extracted 3 times with $1 \mathrm{~L}$ of ethyl acetate. Chromatographic separation coupled to activity-based screening against $L 929$ mouse fibroblasts cells, allowed us to isolate four known compounds: arundine (1), ${ }^{4}$ vibrindole $A(2),{ }^{5}$ 1,1,1-tris(indol-3-yl)methane (3), ${ }^{6}$ 7,7-bis(indol-3yl)-p-cresol (4) ${ }^{7}$ along with one novel compound (5) (Fig. 1). Compounds 1-4 were identified by comparison with spectral data $\left({ }^{1} \mathrm{H}\right.$ and ${ }^{13} \mathrm{C}$ NMR, and MS) previously reported in the literature. ${ }^{5-8}$ 


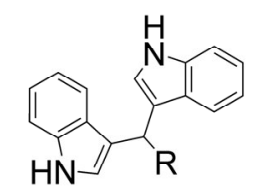

1: $\mathrm{R}=\mathrm{H}$

2: $\mathrm{R}=\mathrm{CH}_{3}$

3: $\mathrm{R}=$ Indol-3-yl

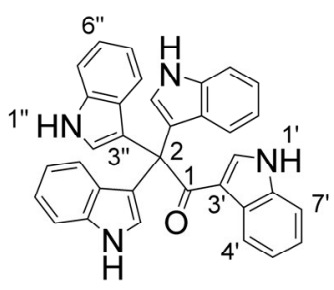

4: $R=4-H y d r o x y p h e n y l$

Tetra(indol-3-yl)ethanone

5

Figure 1. Structures of compounds 1-5.

\section{Table 1}

NMR spectroscopic data for tetra(indol-3-yl)ethanone (5) in $\mathrm{CD}_{3} \mathrm{OD}$

\begin{tabular}{|c|c|c|c|c|}
\hline position & $\delta_{c}$, type & $\delta_{\mathrm{H}}(\mathrm{J}$ in $\mathrm{Hz})$ & cosY & $\mathrm{HMBC}^{\mathrm{a}}$ \\
\hline 1 & 198.4, C & & & \\
\hline 2 & $57.8, \mathrm{C}$ & & & \\
\hline $2^{\prime}$ & $135.8, \mathrm{CH}$ & $7.23, \mathrm{~s}$ & & $1,3^{\prime}, 7^{\prime} a, 3^{\prime} a$ \\
\hline $3^{\prime}$ & $117.5, \mathrm{C}$ & & & \\
\hline 3'a & $128.9, \mathrm{C}$ & & & \\
\hline $4^{\prime}$ & $123.5, \mathrm{CH}$ & $8.43, \operatorname{brd}(7.5)$ & $5^{\prime}$ & $6^{\prime}, 7^{\prime} a$ \\
\hline $5^{\prime}$ & 123.1, CH & $7.17, \operatorname{td}(7.2,1.2)$ & $4^{\prime}$ & 3'a, 7' \\
\hline $6^{\prime}$ & $123.9, \mathrm{CH}$ & $7.15, \mathrm{~m}$ & 7' & $4^{\prime}, 7^{\prime} a$ \\
\hline $7^{\prime}$ & $112.6, \mathrm{CH}$ & $7.28, \mathrm{brd}(7.9)$ & $6^{\prime}$ & $3^{\prime} a, 5^{\prime}$ \\
\hline 7'a & $137.0, \mathrm{C}$ & & & \\
\hline 2" & $125.8, \mathrm{CH}$ & $6.94, \mathrm{brs}$ & & 3", 3"a, 7"a \\
\hline 3" & $121.0, \mathrm{C}$ & & & \\
\hline 3"a & $129.4, C$ & & & \\
\hline 4" & $122.9, \mathrm{CH}$ & 7.14, brdd $(7.2,1.2)$ & $5 "$ & \\
\hline $5 "$ & $119.4, \mathrm{CH}$ & 6.65, brt $(7.5)$ & 4", 6" & 3"a, 7" \\
\hline $6^{\prime \prime}$ & $122, \mathrm{CH}$ & 6.91, brt (7.5) & 5", 7" & 4", 7"a \\
\hline 7" & $112.1, \mathrm{CH}$ & $7.26, d(8.0)$ & 6" & $3 " a, 5 "$ \\
\hline 7"a & $138.5, \mathrm{C}$ & & & \\
\hline
\end{tabular}

${ }^{\mathrm{a}} \mathrm{HMBC}$ correlations, optimized for $8 \mathrm{~Hz}$, are from proton stated to the indicated carbon.

Compound $\mathbf{5}$ was obtained as an intense red powder. The HRESI-MS analysis of $\mathbf{5}$ indicated a molecular formula of $\mathrm{C}_{34} \mathrm{H}_{24} \mathrm{~N}_{4} \mathrm{O}$, from an exact monoisotopic experimental mass at $m / z 527.1844 \mathrm{Da}$ for $[\mathrm{M}+\mathrm{Na}]^{+}$(calcd. 527.1848), corresponding to a compound with 25 degrees of unsaturation. The first impression based on one-proton NMR signal integrations was that we had obtained a 3:1 
mixture of two simple aromatic compounds. Eventually, careful analysis demonstrated that $\mathbf{5}$ was in fact a pure compound with three equivalent indoles.

On one side of the molecule, the ${ }^{1} \mathrm{H}$ NMR spectrum was very similar to the spectra recorded for indole moieties in compounds 1-4, with one singlet at $\delta 6.93(\mathrm{H} 2$ "), and an ortho-disubstituted benzene ring 4-spin system at $\delta 7.13\left(\mathrm{H} 4^{\prime \prime}\right), 6.64$ (H5"), 6.90 (H6") and 7.24 (H7"). HMBC correlations between the singlet proton at $\delta 6.93$ and 3 quaternary carbons at $\delta 138.5$ (C7"a), 129.4 (C3"a) and 121.0 (C3") ppm confirmed the presence of a 3-substituted indole moiety.

On the other side, a second ortho-disubstituted benzene ring was identified based on the four proton signals at $\delta 8.42\left(\mathrm{H} 4^{\prime}\right), 7.14\left(\mathrm{H} 5^{\prime}\right), 7.16\left(\mathrm{H}^{\prime}\right)$, and $7.27\left(\mathrm{H} 7^{\prime}\right)$ along with their COSY and $\mathrm{HMBC}$ correlations. Another singlet proton was present at $\delta 7.22\left(\mathrm{H} 2^{\prime}\right)$. This proton was coupled to quaternary carbons at $\delta 117.5\left(\mathrm{C3}^{\prime}\right), 128.9$ (C3'a) and $137.0\left(\mathrm{C7}^{\prime} \mathrm{a}\right)$, these last two carbons being also coupled to $\mathrm{H}^{\prime}$ and $\mathrm{H}^{\prime}$, and to $\mathrm{H}^{\prime}$ and $\mathrm{H}^{\prime}$, respectively. This pattern indicated that this portion of the molecule was also an indole moiety, although some protons and carbons (H2'/C2', H4'/C4') were significantly shifted downfield indicating that an electron withdrawing group was linked to C3'. Indeed, $\mathrm{H}^{\prime}$ ( $\delta 7.22 \mathrm{ppm}$ ) was correlated to a carbonyl group at $\delta 198.4 \mathrm{ppm}(\mathrm{C} 1)$, although the correlation was very weak.

Based on HRESIMS, one quaternary carbon at $\delta 57.8 \mathrm{ppm}$ had to be added to the structure. The free valences and the 3:1 relative stoichiometry between the indole moieties indicated that this signal should correspond to $\mathrm{C} 2$, on which three indole groups were attached. To test this hypothesis HRMS fragmentation experiments at $30 \mathrm{eV}$ were conducted on the $[\mathrm{M}+\mathrm{Na}]^{+}$adduct of $\mathbf{5}$. The main fragments had $\mathrm{m} / \mathrm{z} 383.1390$ and $\mathrm{m} / \mathrm{z}$ 360.1494, corresponding to the (Indole) ${ }_{3} \mathrm{CNa}^{+\bullet}$ radical cation (calcd. for $\mathrm{C}_{25} \mathrm{H}_{18} \mathrm{~N}_{3} \mathrm{Na}^{+\bullet} 383.1393$ ) and the tri(1H-indol-3-yl)methylium ion (calcd. for $\mathrm{C}_{25} \mathrm{H}_{18} \mathrm{~N}_{3}{ }^{+}$ 360.1495), respectively. Both daughter ions originate from the breaking of the C1-C2 single bond, 
therefore confirming the proposed structure for compound $\mathbf{5}$ which was named tetra(indol-3-

yl)ethanone based on IUPAC convention.

The cytotoxicity of compounds 1-5 was measured using the ATP-lite test (Perkin Elmer) on L929 mouse fibroblasts and on A549 human adenocarcinoma cell lines with 72 hours of contact. Each test was conducted three times in triplicate. The results are reported in Table 2. The new compound $\mathbf{5}$ was significantly cytotoxic, with half maximal effective concentration (EC50) between 7 and $8 \mu \mathrm{M}$.

\section{Table 2}

Cytotoxicity of compounds 1-5 against L929 and A549 cells

\begin{tabular}{lll}
\hline & $\mathrm{EC}_{50}(\mu \mathrm{M})$ \\
\cline { 2 - 3 } & $\mathrm{L} 929$ & $\mathrm{A549}$ \\
\hline Arundine (1) & $>100$ & $>100$ \\
Vibrindole A (2) & $>100$ & $>100$ \\
1,1,1-Tris(indol-3-yl)methane (3) & $>100$ & $>100$ \\
7,7-Bis(indol-3-yl)-p-cresol (4) & 27.4 & 28.0 \\
Tetra(indol-3-yl)ethanone (5) & 7.0 & 8.0 \\
Doxorubicin & 0.25 & 0.5 \\
\hline
\end{tabular}

This report is the first description of tetra(indol-3-yl)ethanone (5) that has been isolated from Pseudovibrio denitrificans BBCC725 along with known analogous indole alkaloids. Although the cytotoxicity of $3,3^{\prime}$-diindolylmethane derivatives has been previously described, ${ }^{9}$ it is interesting to point out that tetra(indol-3-yl)ethanone (5) was the most active of all five compounds (1-5) tested by our assays.

\section{Acknowledgments}

The authors are very grateful to Institut de Recherche et Développement (IRD) and Dr. Cécile Debitus for the water sampling during the SMV4 Cruise Campaign (http://dx.doi.org/10.17600/7100040). We thank the Vanuatu government for the sampling permission. 


\section{$\underline{\text { References }}$}

1. Debbab A, Aly AA, Lin WH, Proksch P. Microb. Biotechnol. 2010; 3:544.

2. Fenical W. Chem. Rev. 1993; 93:1673.

3. Hagström A, Pommier T, Rohwer F, Simu K, Stolte W, Svensson D, Zweifel UL. Appl. Environ. Microbiol. 2002; 68:3628.

4. Khuzhaev BU, Aripova SR, R. Sh. Shakirov RS. Chem. Nat. Compd. 1994; 30:635.

5. Bell R, Carmeli S, Sar N. J. Nat. Prod. 1994; 57:1587.

6. Veluri R, Oka I, Wagner-Döbler I, Laatsch H. J. Nat. Prod. 2003; 66:1520.

7. Cuong PV, Cuc NTK, Quyen VT, Binh PT, Van Kiem P, Nam NH, Dat NT. Nat. Prod. Sci. 2014; 20:202.

8. Li D, Wu T, Liang K, Xia C. Org. Lett. 2016; 18:2228.

9. Cai S-X, Li D-H, Zhu T-J, Wang F-P, Xiao X, Gu Q-Q. Helv. Chim. Acta. 2010; 93:791. 


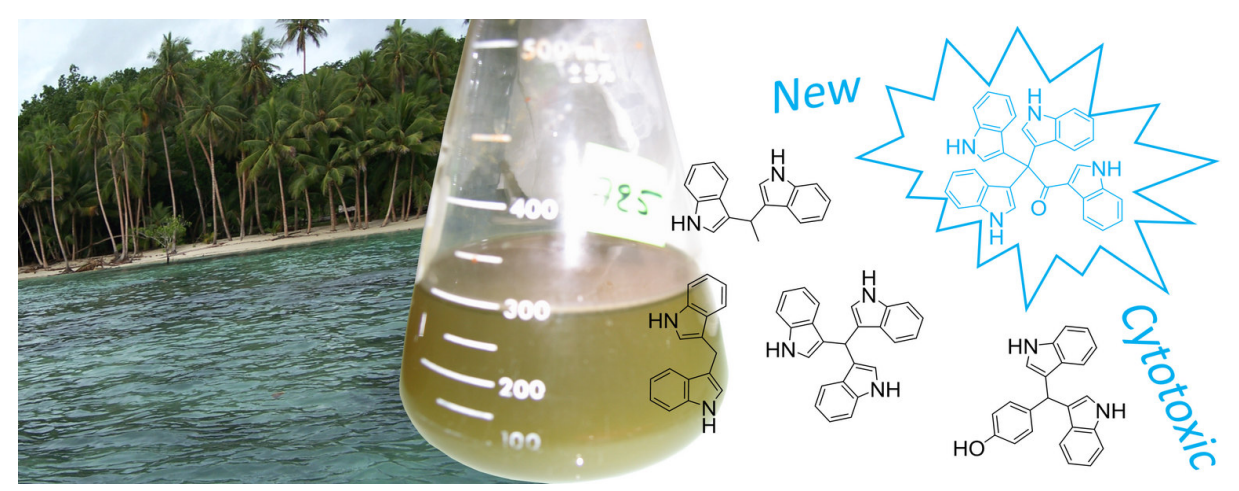


- Five indole alkaloids were isolated from Pseudovibrio denitrificans

- Full description of the new alkaloid tetra(indol-3-yl)ethanone is provided

- Tetra(indol-3-yl)ethanone is cytotoxic 